\title{
Circulation of Vita et Transitus Sancti Hieronymi along the Eastern Adriatic Coast in the Late Middle Ages
}

\author{
Prisotnost Vita et Transitus Sancti Hieronymi vzdolž \\ vzhodne jadranske obale v poznem srednjem veku
}

\begin{abstract}
The Vita et Transitus Sancti Hieronymi was a main devotional work upon which the humanist and the renaissance cult of Saint Jerome was built, testified by a large number of manuscript copies, and printed editions of the work. This paper explores the previously unacknowledged presence of the work in the Eastern Adriatic Coast, especially in the Dalmatian communes, where Jerome has been praised as a national saint since the $15^{\text {th }}$ century. Based on the archival documents, quotations of the Transitus in other written works, and its use as a textual model for the visual representations, it discusses the direct and indirect influence on the promotion of veneration of Jerome. Furthermore, it contributes to the notion of the exchange of ideas and artistic models between two shores of the Adriatic Sea during the Late Middle Ages.
\end{abstract}

Key Words: Transitus sancti Hieronymi, Dalmatia, communes, humanism, renaissance

Izvleček: Vita et Transitus Sancti Hieronymi je bilo glavno pobožno delo, na katerem je bil osnovan humanistični in renesančni kult svetega Hieronima z velikim številom rokopisnih kopij in tiskanih izdaj dela. Ta članek raziskuje prej nepriznano prisotnost dela na vzhodni jadranski obali, zlasti v dalmatinskih skupnostih, kjer je Hieronim že od petnajstega stoletja hvaljen kot narodni svetnik. Na podlagi arhivskih dokumentov, citatov Tranzita $v$ drugih pisnih delih in njegove uporabe kot besedilnega modela za vizualne predstavitve razpravlja o neposrednih in posrednih vplivih na spodbujanje Hieronimovega čaščenja. Poleg tega prispeva k pojmu izmenjave idej in umetniških modelov med obema obalama Jadranskega morja v poznem srednjem veku.

Ključne besede: Transitus Sancti Hieronymi, Dalmacija, skupnosti, humanizem, renesansa 


\section{Introduction}

Is there any other saint of the late Middle Ages whose cult reflects the spiritual, cultural, artistic and political atmosphere of a period more than Saint Jerome? From the $14^{\text {th }}$ century onwards, the figure of this church father, renowned primarily for his translation of the Bible, his commentaries, and the letters he exchanged regularly with his friends, was transformed and adapted to different contexts of veneration - from the church reforms to rising humanist culture. ${ }^{1}$ The fundamental work on the development of Jerome's cult, entitled Saint Jerome in Renaissance by Eugene Rice (1985), covers many of these aspects in detail and portrays the importance and the popularity of Jerome during the later Middle Ages. In the rising reform movements of the monastic orders, Jerome's renunciation of material goods and the ecclesiastical privileges made him an aspirational model. With the development of humanism, his image became the embodiment of the pious and educated life that humanists were pursuing. His repentant nature made him appealing as a personal saint. Due to the number of preserved manifestations of the cult - altars and altarpieces consecrated to the saint, copies of his letters and works, the number of his namesakes, devotional literature - Jerome should be recognized as a renaissance saintly superstar in Europe. (De Vries 1999, 189-99)²

The dissemination of Jerome's vita and other hagiographic material contributed to the easy reception of his cult beyond Italy, where it originated at the end of the $13^{\text {th }}$ century in the church of Santa Maria Maggiore. ${ }^{3}$ Jerome's vita was incorporated into a number of texts, including Jacopo da Voragine's Legenda Aurea (c. 1260), through which it was widespread

1 On Jerome's life and legacy see Kelly (1998); Lössl and Cain (2009).

2 From the end of the $14^{\text {th }}$ century, a considerable number of private chapels were consecrated to Jerome. In Florence, the Del Pugliese family had a chapel in the church of Santa Maria del Carmine with the frescoes made by Starnina between 1402 and 1404, most presumably using the text discussed in this paper as the written source for the depictions of Jerome's Last will and Funeral. The Del Palagio family's chapel in the Florentine church of San Michele Visdomini was decorated with the scenes from his vita at the end of the $14^{\text {th }}$ century. Such practice continued during the $15^{\text {th }}$ century around Italy. Girolamo Badoer built his funerary chapel in the Venetian church San Francesco della Vigna and consecrated it to his namesake Jerome, in the second half of the $15^{\text {th }}$ century (Zelić 2007). In Dalmatia, the earliest private chapel consecrated to Jerome was built by Nicoletta Sobota in 1446, adjoined to the Cathedral of Saint Lawrence in Trogir.

3 I presented this issue at Cantieri dell'agiografia III (Rome, 16-18 January 2019). The paper has been published: Ivić, Ines. 2020. »Recubo praesepis ad antrum«: The Cult of Saint Jerome in the Church of Santa Maria Maggiore in Rome at the End of the $13^{\text {th }}$ Century. Il Capitale culturale 21: 87-119. 
during the Middle Ages, as well as another version, composed by Niccolò Maniacoria which also circulated widely in manuscript, although with a lesser impact. ${ }^{4}$ The greatest influence on the expansion of Jerome's cult, principally during the Renaissance, had three apocryphal letters by PseudoEusebius, Pseudo-Cyril of Jerusalem and Pseudo-Augustine. These letters were already dispersed around Europe in the first half of the $14^{\text {th }}$ century and subsequently translated into vernacular languages, and when compiled together with Jerome's vita and prayers to the saint, came to be known also under the joint name Vita et Transitus Sancti Hieronymi (further in text Transitus). ${ }^{5}$ The popularity of this combined work was further boosted when it was released in printed editions during the last decades of $15^{\text {th }}$ century.

\section{Vita et Transitus Sancti Hieronymi}

The letters contained in the Transitus played a large role in spreading the cult of Jerome, especially during the renaissance, when they became the main devotional material and the source for the narration of Jerome's life. Eusebius of Cremona, one of Jerome's disciples and his successor in the apostolic mission to Bethlehem, in a letter known as Epistola beati Eusebii de morte gloriosissimi Hieronymi doctoris eximii, addressed to Damasus, Bishop of Porto, and Theodosius, a Roman senator, describes Jerome's last moments and death (Socii Bollandini 1898, 3867; Migne 1845, 239). ${ }^{6}$ The second letter, Epistola sanctii Augustini Hipponensis episcopi ad Cyrillum Jerosolymitanum episcopum de magnificentiis beati Hieronymi, addressed to Cyril by Augustine, recalls the first one, describing the apparition of Jerome's soul to Augustine in Hippo at the time of Jerome's death in Bethlehem (BHL, 3867; PL, 22: 282-89).7 The last letter, Epistola

4 For more clarification see the Chapter 2 From History to Legend. Rice, Saint Jerome in the Renaissance, 23-48. On the circulation of Jerome's vitae see also Russo (1987, 20-26.38-44).

5 On the dissemination of the letters in Central Europe and their vernacular translations see Korondi (2018, 193-214).

6 The letter is also known under these titles: Epistola de morte Hieronymi, Epistola ad Damasium episcopum de morte gloriosissimi Hieronymi, Epistola del transito di S. Hieronymo, De morte Hieronymi or Transitus diui Hieronymi per Eusebium Cremonensem eiusdem Hieronymi discipulum sanctissimum editus incipit (Russo 1987, 157). For detailed analysis see Lizzi Testa (2007, 303-40).

7 Also known as Epistola de magnificentiis Hieronymi ad Cyrillum. 
de miraculis Hieronymi, contains Cyril's response to Augustine, and it brings an important novelty - miracles Jerome performed during his lifetime and after his death (BHL, 3868; PL, 22: 289-326). ${ }^{8}$

Scholars now agree that the letters were forged to fulfill the inconsistencies in Jerome's life, primarily his last days, and to enrich his vita with miracles so he could be more appealing to the devotees (Rice 1985, 30). ${ }^{9}$ There is no scholarly consensus however, on when this forgery occurred. Cavallera suggests that the author of the Pseudo-Eusebius' letter was different from the author of the other two, suggesting that Pseudo-Eusebius' letter was of an earlier twelfth century production (Cavallera 1922, 56-63). However, Francesco Lanzoni, in his analysis of the three letters, asserts that all three were produced in the same period, connecting the author of these letters with the author of the text describing the translation of Jerome's body from Bethlehem to Rome (Translatio) composed after 1280s $(1920,38){ }^{10}$ Eugene Rice agrees on the similarity between the style and the purpose of these letters with the text of Translatio, which indicates that they were forged in a unique ideological project, but asserts that the letters were forged a bit later than the Translatio, most probably at the beginning of the $14^{\text {th }}$ century. Rice's theory $(1985,219)$ that they were all forged at the same time by the same author is supported by the fact that they were usually thereafter reproduced together as a unit.

The letters' influence is visible in the major works of Jerome's $14^{\text {th }}$-century hagiography, starting with Giovanni d'Andrea's Hieronymianus liber (c. 1348), and continuing with Pietro Calò who incorporated them into Jerome's legend in his Legendae de Sanctis (before 1340), and by Petrus

8 Other known titles are Liber cyrilli de miraculis diui Hieronymi ad beatum Augustinum, Epistola ad beatum Augustinum de miraculis Hieronymi, Responsio Cyrilli ad Augustinum de miraculis B. Hieronymi.

9 The author of Hieronymus noster gives some brief information on Jerome's last days saying that he was so sick that he used a rope above his bed to lift himself up.

10 The text of Translatio describes the event of the relocation of Jerome's bodily remains from Bethlehem to the church of Santa Maria Maggiore in Rome, after Jerome appeared in a vision to a monk. According to the legend connected with the church, it happened in 1283, while the text of the event was written down in the 1290s. 
de Natalibus in his Catalogum Sanctorum (1372) (Rice 1985, 49). ${ }^{11}$ Through these transcriptions, the content of the Transitus spread across Europe, promoting Jerome's cult with new added material, mainly miracles. The scholars have so far managed to identify more than 400 manuscript copies containing the letters, or at least parts of them (Rice 1985, 219). The number of printed editions, which in Venice alone was 14 between 1475 and 1498, and out of which 12 were in vernacular, shows the great popularity of the saint, with many wanting a copy of this work in their personal libraries. (Brown and Ferino-Pagden 2006, 132)

The main reason for the compilation of such hagiographic material on Saint Jerome lies in the fact that not much is known of the historical Jerome. His letters reveal much on the lives of his contemporaries, but none of them returned the favor (Cavallera 1922, V). What was known about Jerome, came primarily from his own words, an autobiography, included in his De viris illustribus (Jerome 2010, 267). This paucity of sources from Jerome's time, which could help us draw his image, left ample space for later medieval interventions and inventions regarding the saint, especially the miracles that he performed, which could be used to form his saintly image according to the religious needs and sentiments of the era. Yet, despite its importance to the dissemination of Jerome's cult and its influence on the formation of the iconographic types of saint present in artistic representations, the Transitus had still awaited a thorough study.

\section{Dissemination of the work in the Eastern Adriatic Coast}

While the Transitus as a whole still deserves a thorough treatment by scholars, this paper observes the presence and influence of this work in the cultural production of the Eastern Adriatic Coast where Jerome held particular importance. Jerome's special status in the region was due in large part to the belief that his birthplace was in the territory of Dalmatia.

11 Out of a strong personal devotion and admiration for the saint, Giovanni d'Andrea, a canon from Bologna and a professor of law at the University of Bologna, composed a book Hieronymianus or De Laudibus de Sancti Hieronymi containing earlier written lives of Jerome, evidence of his miracles, testimonies of his glory and a selection of Jerome's works. He also promoted the veneration of the saint then by his own actions, naming his son Jerome, painting the façade of his house with the scenes from Jerome's vita, and building and consecrating churches to Jerome. 
From this starting point, the cult of Jerome arose among the Glagolitic monks who saw him as the inventor of the Glagolitic script, composer of the Slavic mass and translator of the Bible into the Old-Church Slavonic (Verkholantsev 2014; Badurina Stipčević 2013, 17-26). From the $15^{\text {th }}$ century, the earlier Glagolitic interest combined with the rise of humanism and the renaissance fed the general popularity of Jerome, and he began to be venerated as a national saint in Dalmatia. ${ }^{12}$ The cult flourished in the Dalmatian communes like Zadar, Šibenik, Trogir, and Dubrovnik, manifesting in altars, chapels, altarpieces and devotional works. This study observes the development of the cult by analyzing the presence and influence of the Transitus in written and visual works present in these communes. The main obstacle to this research is the lack of preserved manuscript copies of Transitus whose provenance can be linked to Dalmatia. This lack of direct manuscript evidence could lead to the conclusion that during the Late Middle Ages, the text of the Transitus was not known at all in Dalmatia. Still, by employing a comparative and interdisciplinary approach, incorporating different types of sources, this paper will argue that its influence, direct or indirect, was stronger than had previously been thought and that the printing of Croatian vernacular edition of Transitus in Senj in 1508 was the culmination of the popularity of Jerome's cult in the Eastern Adriatic Coast (Štefanić 1964, 99-161; Nazor 1999, 249-55).

In the Eastern Adriatic Coast, the letters included in the Transitus were known primarily in Glagolitic translations and transcripts. The Ivančević Miscellany from the turn of the $14^{\text {th }}$ to $15^{\text {th }}$ centuries contains the transcript of Augustine's epistle to Cyril and Cyril's reply to Augustine, while the parts of Eusebius's letter are found among the Glagolitic fragments (Fragm. glag. 77) kept in the Archives of the Croatian Academy of Arts and Sciences (Štefanić 1964, 106-107, 122-123). Taking into consideration the important place that Jerome had among Glagolites, it is not surprising that

12 This paper continues my previous publications on the development of the cult of Saint Jerome in Dalmatia (Ivić 2016; 2018). The Renaissance cult of Jerome was blossoming in the Dalmatian communes, incorporated into the Republic of Venice since 1420, due to growing humanism and Renaissance culture. However, the ongoing Glagolitic cult which praised Jerome as the inventor of Glagolitic script was present into Dalmatian hinterlands which were at the time, together with medieval Croatia, part of the Kingdom of Hungary. For that reason, when discussing the general presence of the cult I will use the geographical denomination Eastern Adriatic Coast which includes different political entities. When I discuss the presence of the cult in the communes and among the educated humanists and clerics, I will use the term Dalmatian. 
the earliest copies are found in this cultural circle. Until now, no surviving Latin manuscript copies of Dalmatian provenance have been known, unlike the printed ones. However, this research managed to identify the manuscript containing the only surviving copy of Pseudo-Eusebius's letter, transcribed by the hand of Chrysogonus (Krševan) de Nassis in 1469, previously unknown to scholars. The manuscript (Bridwell MS5) is kept in the Bridwell Library of the Southern Methodist University in Dallas, and it consists of three parts: Pseudo-Eusebius' letter to Epistola ad Damasum et Theodorum Senatorem de morte Hieronimi (ff. 1-38v), the vita of Saint Jerome by Nicholas Maniacoria In vita Hieronimi presbiteri [unattributed by the scribe] (ff. 39-53v), and St. Paulinus of Aquileia's De admonitione ad comitem Aurelianum, whom Chrysogonus mistakenly identifies as by Augustine (ff. 54-86r). (MS 5 Pseudo-Eusebius of Cremona and Pseudo-Augustine)

The manuscript is dated twice, November 18, 1469, and December 10, 1469. It seems likely that the ownership of this manuscript by the Nassi family was not accidental as several indicators reveal the particular devotion of the family to this saint. Additionally, the choice of Pseudo-Eusebius' letter which describes the death of Saint Jerome (transitus to heaven) also seems not to have been accidental. A year before Chrysogonus transcribed the manuscript, his father Raphael del Nassis, a prominent judge from Zadar, died. Transcription of the manuscript could have been a way to pay honor to his deceased father. This manuscript also contributes to the notion of the presence of other hagiographic texts. The vita composed by Nicola Maniacoria, written in the $12^{\text {th }}$ century. As the title says Vita sanctii Hieronymi collecta ex tractatibus eius ac sanctorum Augustini, Damasi, Gregorii, Gelasii, et aliorum partum sanctorum was extracted from the writings of other Church fathers and Jerome's contemporaries. In the library of the Franciscan monastery in Zadar, another transcription of this vita is to be found, inserted at the end of the incunabula of Jerome's epistles Epistolae I-II, printed in Parma in 1480. The five parchments written in gothic minuscule were probably written down in the $15^{\text {th }} / 16^{\text {th }}$ century. (Frkin 1990, 136) The presence of Maniacoria's text in Dalmatia shows that despite the ongoing tradition of Jerome's local origin, the imported devotional material was an important factor in the development of Jerome's cult in Dalmatia. The same goes for the text of Transitus. 
Due to the lack of preserved manuscripts, apart from the above mentioned Nassi manuscript, it is necessary to turn to archival data which could help us reconstruct the presence of the copies in Dalmatia. In Zadar, Presbyter Simeon (Šimun) indicated in his testament made in 1467 that he leaves his copy of Transitus to the presbyter Nikola (Stipčević 2012, 55). ${ }^{13}$ In 1490, also in Zadar, Andrew of Bribir (Andrija Bribiranin) states in his testament that a copy of Transitus written on the parchment should be given back to Mauro de Grisogonis, from whom he had borrowed it. ${ }^{14}$ With the invention of the printings press, devotional literature became more popular and accessible. For that reason, in the monastic libraries in Dalmatia, among other literature on Jerome and by Jerome, the incunabula of Transitus, printed mainly in Venice, are also present (Frkin 1990, 179-80). ${ }^{15}$

The direct and indirect influence of Transitus can be read in several examples in Dalmatia. The direct influence must have come from the possession of a copy which was then used to create other devotional material on Jerome. For example, that can be seen in the vita written in 1507 by Marko Marulić, the famous Dalmatian humanist (Novaković 1994, 5-24; Marulić 1994, 26-66). ${ }^{16}$ Inspired by countless falsehoods and insufficiently detailed records of Jerome's life, he wrote a new vita which, due to still unclear reasons, has never been published, although some parts circulated in the manuscript form. It is not necessary to present a detailed analysis of the work in order to portray Transitus as one of the main sources that Marulić used for his biography of Jerome, though it is hoped that such a study will be executed in the future. Already in the title Vita diui Hieronymi pręsbiteri a Marco Marulo ędita: adiectis miraculis que de illo Cyrillus Nazarethi episcopus commemorat in summamque redactis breuiorem, Marulić indicates that he records the selection of Jerome's miracles

13 Državni arhiv Zadar (DAZd), Spisi zadarskih bilježnika (SZB), Nicolaus de Benedictis, 1467, 5. II. Item reliquit supradicto presbitero Nicolao primicerio Transitum Sancti Hieronimi.

14 DAZd, SZB, Hieronymus Vidolich, B un, F V, nr.26. 1490. 28. VI. Item voluit restituisset ser Mauro de Grisogonis eius Transitum Sancti Hieronimi in carta bona. I would like to express my gratitude to Emil Hilje who pointed out to me the existence of this document and shared its transcription with me.

15 A copy of La vita el transito printed in Venice in 1475 by Gabriele Petri can be found in Dubrovnik.

16 Apart from the life, Vita diui Hieronymi, Marulić also wrote the devotional song - De laudibus diui Hieronymi carmen and an important polemical essay on Jerome's origin - In eos qui beatum Hieronymum Italum fuisse contendunt, addressed to Italian humanists who identified Jerome as Italian. 
brought by Pseudo-Cyril in his letter to Augustine, in which he lists Jerome's miracles, presumably from his own copy of one of the Italian incunabula. ${ }^{17}$

The examples from Trogir also reflect the direct influence of the text, even though we could not determine in the archival sources whether such copies were present in this commune. In 1455, the council of Trogir decided to include Jerome's feast day, September $30^{\text {th }}$ on the list of the officially celebrated feast in the commune (Strohal 1915, 259). ${ }^{18}$ Among the reasons why he should be solemnly celebrated were his intellectual deeds, ascetic and devoted lifestyle, numerous miracles performed during life and after death, as well as the fact that he originated from the Dalmatian province. The phrase "numerous miracles during life and after death" refers precisely to the miracles enumerated in the epistle of Cyril, which in some form, most probably the Latin transcript, were known in Trogir (Strohal 1915, 259). ${ }^{19}$

Such work served also as the valuable source of material for the preparation of sermons about the saints. One such sermon is preserved in Trogir and is known in the literature as the Trogir Life of Saint Jerome (Trogirski život svetog Jeronima). The text written in the vernacular Croatian language is preserved in a transcription from the $16^{\text {th }}$ century, most probably based on an earlier version of the text. Previous scholarship assumed that the text was written for the nuns of the Benedictine monastery of Saint Nicholas by some Augustine monk who served the mass for nuns, since the friendship between Saint Jerome and Saint Augustine is emphasized throughout the lines. A closer reading of the text, however, clearly identifies the episodes of Jerome's life which could be found in the apocryphal letters contained in the Transitus. Citations of Pseudo-Augustine's letter can be found, especially in the events of Jerome's death and Augustine's vision

17 For a detailed analysis of the Life of Saint Jerome by Marulić, and the sources he used consult Novaković (2011, 11-39). However, Marulić made a mistake in the title, naming Cyril as the Bishop of Nazareth instead of Jerusalem.

18 Quod dies Sancti Hieronymi sit festus.

19 (...) tum etiam propter miraculorum innumerabilium, quibus perfulsicf(?) in vita et post mortem claritatem (...). 
of Jerome's soul, together with mention of Cyril's letter. (Bratulić 2014, $27-41)$

With the growing cult of Jerome in the Eastern Adriatic Coast, an obvious need for devotional material rose among preachers who needed a translation in the language they were preaching. This, with the general popularity of the book in Italy during this period, should be seen as the reason for the printing of the Glagolitic edition in Senj, in Croatian language. It was the first non-liturgical book printed in the vernacular language and Glagolitic script ${ }^{20}$ translated from the Italian incunabula Transito de Sancto Girolamo (Venice, 1487). (Nazor 1999, 251) ${ }^{21}$

While the cult of Jerome grew more popular in Dalmatia during the $15^{\text {th }}$ century in part due to the increasing popularity of Transitus, in Italy the direct influence of the text is further visible in the iconography of the saint, especially in the narrative scenes such as the Communion of Saint Jerome, Funeral of Saint Jerome or the Apparition of Jerome's soul to Saint Augustine, to our knowledge there were not painted narrative cycles of Jerome's life in Dalmatia (Russo 1987, 151). ${ }^{22}$ Still, its influence is visible in other artworks. One of the iconographic and hagiographic traditions that originate in this apocryphal work is the pairing of Saint Jerome with Saint John the Baptist. The letters emphasize several times the parallel between John the Baptist and Jerome. Pseudo-Eusebius' letter depicts Jerome as new John the Baptist, who, by his ascetic way of life, agreed to be a martyr, witnessing the true doctrines of Christ. In the other two letters, the equaling of these two saints in their holiness is even more

20 Today, ten incomplete copies of Transitus are preserved. Four are kept in in Zagreb at the Library of the Croatian Academy of Sciences and Arts. Of the remaining copies, two are preserved at the National Library in Saint Petersburg, and one copy each at the National Library in Prague, Košljun, Vrbnik and in a private collection.

21 The translation was based on the edition Transito de s. Girolamo (Venezia: Annibale de Foxio da Parma, 1487).

22 The predella of the Gesuati polyptych made for Gesuati church in Sienna by Sano di Pietro in 1444, narrates the events of Jerome's life, following the text of Transitus. The Rinieri altarpiece, made for the Gesuati church in Santa Trinita Vecchia in Florence around 1431 by Francesco d'Antonio di Bartolommeo, also narrates the events from Jerome's life, based on Transitus. In Venice, Lorenzo Bastiani painted Pala di San Girolamo for the cathedral of Asolo in 1485. The predella panels depict scenes from the life of Saint Jerome, including his death. For the Scuola di San Girolamo in Venice, whose member he became in 1470, he painted a cycle of the Life of Saint Jerome, repeating the same scene of Jerome's funeral like it is on predella. Vittore Carpaccio painted Jerome's funeral in his famous cycle in the Scuola di San Giorgio degli Schiavoni at the beginning of the $16^{\text {th }}$ century. 
pronounced. In the description of his vision, Augustine explains to Cyril that John the Baptist appeared in the presence of Saint Jerome and emphasized that he and Jerome were the same in their holiness. Additionally, he prompted Augustine to record all of Jerome's glory. Cyril conveys his vision of Jerome and Saint John the Baptist in the company of Saint Peter and the angels. (Lizzi Testa 2007) 23

Their pairing became a common practice in visual medium, where the two saints are usually depicted one next to each other on the polyptychs as can be seen on famous Massaccio's and Masolino's polyptych executed in 1428-1429 for the chapel of Saint John the Baptist in the church of Santa Maria Maggiore in Rome, today in the National Gallery in London. This typological pairing of the saints is present along the Eastern Adriatic Coast, but its presence is due to the adopted artistic expressions from Italy, rather than the direct influence of the text. In Trogir, they are paired on the altarpiece made by Blaž Jurjev Trogiranin (Biagio da Trau) in 1434 for the altar of Saint Jerome in the church of Saint John the Baptist in Trogir, and on the organ doors, painted by Gentile Bellini in 1489. The altarpiece by Antonio and Bartolomeo Vivarini, made for the Franciscan church in Kampor in 1458, on the island of Rab also pairs the saints in this manner, similarly on the portal of the Franciscan church in Dubrovnik, made by the Petrović brothers in 1498. The two saints were also depicted on the now lost frescoes above the tomb of Ivan Germanov in 1390, in Zadar. (Hilje 1999, 165)

In Trogir, we find an example which points out that such work was known, read and understood well. A renaissance and humanist culture were blossoming during the second half of the $15^{\text {th }}$ century, carried by the activities of prominent individuals such as Coriolano Cippico, Jakov Andreis, Ivan and Jakov Sobota, Ivan Lipavić, Jerome of Trogir, and many other members of local patrician families. The renaissance renovatio urbis, largely conducted by Coriolano Cippco in theory, and by Andrea Alessi and Niccolò Fiorentino in practice, had transformed the small commune into a cultural center. (Ivančević 1997; Bužančić 2012) The most visible transformations were made on the main square and the buildings on the square. The

23 The detailed analysis of pairing of two saints in the letters can be found in the notes 87-91. 
cathedral of Saint Lawrence also underwent refurbishing. Included among the grand scale constructions added to the church were a new baptistery, adjoined to the northwestern corner of the church in 1467 by Andrea Alessi, and the chapel of the Blessed John of Trogir, whose construction was started in 1468 by Niccolò Fiorentino. Here, of interest is the new baptistery, where the monumental relief representing Saint Jerome reading in the cave was inserted in a lunette on the eastern wall. (Josipović 2019, 47-66; Marković 2013, 45-60; Štefanac 1996, 107-19) Previous researchers didn't see this location of Jerome's relief as unusual and connected its execution only with the new status which the saint received in Dalmatia from the middle of the $15^{\text {th }}$ century when he became a universal patron saint of Dalmatia and the Dalmatians. However, the reason for Jerome's inclusion in the decoration is likely related to the previously argued pairing of the two saints, here executed in the architectural setting, in the baptistery which is also a chapel of Saint John the Baptist. The pairing within the baptistery is also evident in the visual sense - the relief of Saint Jerome corresponds to the sculpture of Saint John the Baptist made by Niccolò Fiorentino for the altar beneath the relief. As so far there has been found no comparative material from whence such an iconographic idea could have been adopted in Trogir, we are left to conclude that for this example, as well, we can discuss the direct influence of text of Transitus, possibly possessed by someone from the Trogir humanist circle, or the canons of the cathedral.

\section{Conclusion}

This contribution to the research of the cult of Saint Jerome in Dalmatia has pointed out the important elements of the formation of Jerome's image during the Renaissance when the perception of him as a national saint began. First, it demonstrated how the influence of the Transitus can be noted by its citations in cultural production. Some of these, such as that in Trogir, contain direct citations, suggesting that the Transitus was known and read during the $15^{\text {th }}$ century, even though we don't have direct material evidence of it in Dalmatia. Familiarity with the text by the contemporary Italian cult in Trogir can further be seen in the pairing of Saint Jerome with Saint John the Baptist in the baptistery, in the ideological and visual sense. However, this evidence also shows that when discussing the possible presence and 
impact of the Transitus, we must be aware of possible secondary influence, introduced through the adoption of already established painterly models in Italy.

The presence of the letters contained in the Transitus in the Eastern Adriatic Coast is not surprising, firstly because of their popularity, especially after the invention of the printing press, and secondly due to the proximity of two coasts of the Adriatic sea and the fact that a large portion of the Eastern coast was governed at the time by the Republic of Venice. The Croatian edition of the Transitus from Senj followed the established practices of translating the letters into the vernacular that was to be found in Italy, but it was certainly supported by the wish of Jerome's compatriots to learn more about their patron saint, and therefore symbolically printed in the script they believed was invented by the saint himself.

A more detailed study on the questions raised here will only be made possible with a thorough exploration of archival material and a search for other citations referencing the Transitus in the works of Dalmatian humanists, and in artworks representing Jerome. Until then, this study opens the question of not only the presence of the manifestations of Jerome's cult, but also of the transference of knowledge and ideas between the two coasts of the Adriatic Sea, in which Saint Jerome's cult had a special place. 


\section{References}

Badurina Stipčević, Vesna. 2013. Legenda o Jeronimu u starijoj hrvatskoj književnoj tradiciji. Wiener Slawistischer Almanach 85: 17-26.

Bratulić,Josip. 2014 Trogirski (Jagićev) život svetog Jeronima: U spomen na Vatroslava Jagića u povodu 90. obljetnice smrti. Zadarska Smotra 1-2: 27-41.

Brown, David Alan, and Sylvia Ferino-Pagden, eds. 2006. Bellini, Giorgione, Titian, and the Renaissance of Venetian Painting. Washington; Vienna: National Gallery of Art; Kunsthistorisches Museum.

Bužančić, Radoslav. 2012. Nikola Ivanov Firentinac i trogirska Renovatio Urbis. Split: Književni krug.

Cavallera, Ferdinand. 1922. Saint Jérôme: sa vie et son oeuvre. Louvain: Spicilegium Sacrum Lovaniense.

De Vries, Anneke. 1999. Two Copies after Starnina's Lost Frescoes in Santa Maria Del Carmine. Mitteilungen Des Kunsthistorischen Institutes in Florenz 43: 189-99.

Frkin, Vatroslav. 1990. Katalozi inkunabula crkvenih ustanova u Hrvatskoj. IV. zbirka inkunabula u knjižnicama franjevačke Provincije sv. Jeronima. Prvi dio. Croatica Christiana Periodica 14: 121-204.

Hilje, Emil. 1999. Gotičko Slikarstvo u Zadru. Zagreb: Matica hrvatska.

Ivančević, Radovan. 1997. Rana Renesansa u Trogiru. Split: Književni krug.

Ivić, Ines. 2016. Jerome Comes Home: The Cult of Saint Jerome in Late Medieval Dalmatia. Hungarian Historical Review 5: 618-44.

- - -. 2018. The 'Making' of a National Saint: Reflections on the Formation of the Cult of Saint Jerome in the Eastern Adriatic. Il Capitale Culturale Supplementi 7: 247-78.

Jerome, Saint. 2010. On Illustrious Men. Translated by Thomas P. Halton. Washington: CUA Press.
Josipović, Ivan. 2009. Nikola Firentinac i Alešijeva Krstionica Trogirske katedrale. Radovi Instituta za povijest umjetnosti 33: 47-66.

Kelly, J. N. D. 1998. Jerome: His Life, Writings, and Controversies. Peabody: Hendrickson.

Korondi, Ágnes. 2018. A Vita et transitus Sancti Hieronymi kelet-közép-európai és magyarországi elterjedéséról. In: A könyv és olvasója: a 14-16. századi könyvkultúra interdiszciplináris megvilágításban, 193-214. Budapest: MTA-ELTE HECE.

Lanzoni, Francesco. 1920. La leggenda di S.Girolamo. In: Miscellanea Geronimiana. Scritti varii pubblicati nel XV centenario dalla morte di San Girolamo, 19-42. Roma: Tipografia Poliglotta Vaticana.

Lizzi Testa, Rita. 2007. The Ascetic Portrayed: Jerome and Eusebius of Cremona in the Italian Art and Culture of the Renaissance. In: From Rome to Constantinople: Studies in Honour of Averil Cameron, 303-40. Leuven; Paris; Dudley: Peeters.

Lössl, Josef, and Andrew Cain. 2009. Jerome of Stridon: His Life, Writings and Legacy. Farnham: Ashgate Publishing.

Marković, Predrag. 2013. Dekonstrukcija rekonstrukcije: o krstionici trogirske katedrale ponovo is razlogom. Radovi Instituta za povijest umjetnosti 37: 45-60.

Marulić, Marko. 1994. Vita diui Hieronymi pręsbiteri a Marco Marulo ędita: adiectis miraculis quę de illo Cyrillus Nazarethi episcopus commemorat in summamque redactis breuiorem. Colloquia Maruliana 3: 26-66.

Migne, J. P. 1845. Patrologia Latina. Vol. 22.

MS 5 Pseudo-Eusebius of Cremona and PseudoAugustine. Https://sites.smu.edu/bridwell/ specialcollections/bridwellwesternms/ms5.htm (accessed: January 28, 2020). 
Nazor, Anica. 1999. Senjski tranzit svetoga Jerolima i hrvatski rječnik do Marulića i njegovih suvremenika. Rasprave: Časopis Instituta za hrvatski jezik $i$ jezikoslovlje 25: 249-55.

Novaković, Darko. 1994. Novi Marulić: Vita diui Hieronymi. Colloquia Maruliana 3: 5-24.

- - -. 2011. Svetac sa sretnog dalmatinskog žala: Marulićev životopis Sv. Jeronima. In: Vedran Gligo, Veljko Gortan, Neven Jovanović, Darko Novaković, and Vladimir Rezar, eds. Marko Marulić: Latinska Manja Djela II, 11-39. Split: Književni krug.

Rice, Eugene F. 1985. Saint Jerome in the Renaissance. Baltimore: Johns Hopkins University Press.

Ridderbos, Bernhard. 1984. Saint and Symbol: Images of Saint Jerome in Early Italian Art. Groningen: Bouma's Boekhuis.

Russo, Daniel. 1987. Saint Jérôme en Italie: étude d'iconographie et de spiritualité (XIIIe-XVe siècle). Paris; Rome: Découverte; Ecole française de Rome.
Socii Bollandini, ed. 1898. Bibliotheca Hagiographica Latina Antiquae et Mediae Aetatis, Bd. 1-2, Ed. by Socii Bollandini. Bruxelles.

Štefanac, Samo. 1996. Osservazioni sui rilievi di S. Girolamo nel deserto dalla cerchia di Niccolò di Giovanni Fiorentino e Andrea Alessi. Prilozi povijesti umjetnosti u Dalmaciji 36: 107-19.

Štefanić, Vjekoslav. 1964. Glagoljski tranzit svetog Jeronima u starijem prijevodu. Radovi Staroslavenskog instituta 5: 99-161.

Stipčević, Aleksandar. 2012. Djela Antičkih Pisaca u Srednjovjekovnom Zadru. Croatica et Slavica Iadertina 8: 47-88.

Strohal, Ivan, ed. 1915. Statut i reformacije grada Trogira. 10. Zagreb: JAZU.

Verkholantsev, Julia. 2014. The Slavic Letters of St. Jerome. DeKalb, IL: NIU Press.

Zelić, Danko. 2007. Nekoliko priloga povijesti umjetnosti 15. stoljeća u Trogiru: Samostan sv. Križa na Čiovu, zlatar Matej Pomenić i kapela sv. Jeronima u katedrali sv. Lovre. Peristil 50: 63-80. 